\title{
Identification of New Compounds from Catharanthus roseus Hairy Root Cultures
}

\author{
III-Min Chung, Mohd Ali, ${ }^{+}$Young-Mok Yang," Christic A. M. Peebles, ${ }^{*}$ Sc-Chul Chun, \\ Sun-Joo Lec, Ka-Yiu San, ${ }^{, *}$ and Ateeque Ahmad ${ }^{*}$ \\ Department of Applied Life Science, Konkuk University, Seoul 143-701, Korea. "E-mail: aahmado ay ahoocom \\ "Factly of Pharmacy, Handard Universit, New Delhi-l10062, India \\ ${ }^{\ddagger}$ Department of Pathology, School of Medicine, Konkuk University, ChungJu 380-701, Korea \\ Departmen of Bioengineering, Rice University, Houston, Texas 77005, USA. "E-mail: ksanarice.edu \\ Received May I4, 2007
}

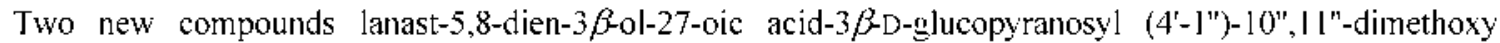
anthracene (1). 2-methoxy-6-(n-nonacontan-5".6"-dionyl)-1 ]-hydroxy-13-methyl-I | $\beta$-D-rhamnopyranoside anthracene (2) have been isolated from the hairy root cultures of Catharamins rosets. Their structures have been elucidated with the help of $500 \mathrm{MHz}$ NMR using one- and two-dimensional NMR in combination with IR, EI/MS, FAB/MS and HRFABMS spectroscopy.
\end{abstract}

Key Words : Cathoranthes roseus, $\Lambda$ pocynaceae, Cultures hairy roots. New constituents.

\section{Introduction}

The periwinkle, Cahoranthus roweus (Apocynaccac), is a widely used omamental and medicinal plant. C. roseus is an herbaccous shrub' and has been extensively studied due to its production of two valuable alkaloids, vincristine and vinblastine which are used in the treatment of human neoplasm, and an alkaloid from the root, ajmalicine which is used in the treatment of circulatory disorders and hypertension. Biologically indole alkaloids produced by plants are believed to play a role as antimicrobial and antifeeding compounds. ${ }^{2.3}$ This madagascan periwinkle produces numerous indole alkaloids which have important therapeutic activities. ${ }^{4}$ Only few phenolic compounds have been reported in this genus. " Recently, two flavonols trisaccharides of kaempferol and quercetin have been isolated and identified. ${ }^{7}$ Several indole alkaloids have been isolated from the $C$. rosens cell suspension cultures. "However, the production of the most valuable compounds reported from this plant. vincristine and vinblastine that are terpenoid indole alkaloids, ${ }^{10}$ has not yet been achieved in these cultures. Besides indole alkaloids, the presence of anthocyanidins." phenolics, ${ }^{17} 12$ and terpenoid compounds ${ }^{8.9}$ in the cultures of $C$. rosens has been reported. As part of its secondary metabolism this plant produces pharmaceutically valuable terpenoid indole alkaloids such as vincristine and vinblastine which are used as anticancer drugs. A very low yield of these compounds is a major motivation of the research interest in this plant. Although the hairy root cultures do not produce these two bisindole alkaloids that consist of catharanthine and vindoline, they have been shown to produce catharanthine and tabersonine. This paper deals with the isolation and structural elucidation of two new compounds ( 1 ) and (2) on the basis of spectral data and chemical reactions and also reported one new and three known compounds, $\beta$-sitosterol, 3-epibetulinic acid, $n$-pentadecanyl octa-dec-19-en-oate. ${ }^{13}$ Due to high significance of medicinal natural products of these plants roots the work such as terpenoids, alkaloids analysis has extensively been conducted. The aim of the present investigation is to report some of the new findings in the forn of natural product from culture roots of $C$, roseus.

\section{Results and Discussion}

Compound 1 , was obtained as a dark yellow crystalline mass and its molecular formula $\left.\left(\mathrm{C}_{52}\right]_{70} \mathrm{O}_{10}\right)$ was deduced from HR-FABMS. It gave positive tests for triterpenic glycosides and produced effervescences with sodium bicarbonate indicating the presence of carboxylic acid in the molecule. Its IR spectrum showed characteristic absorption

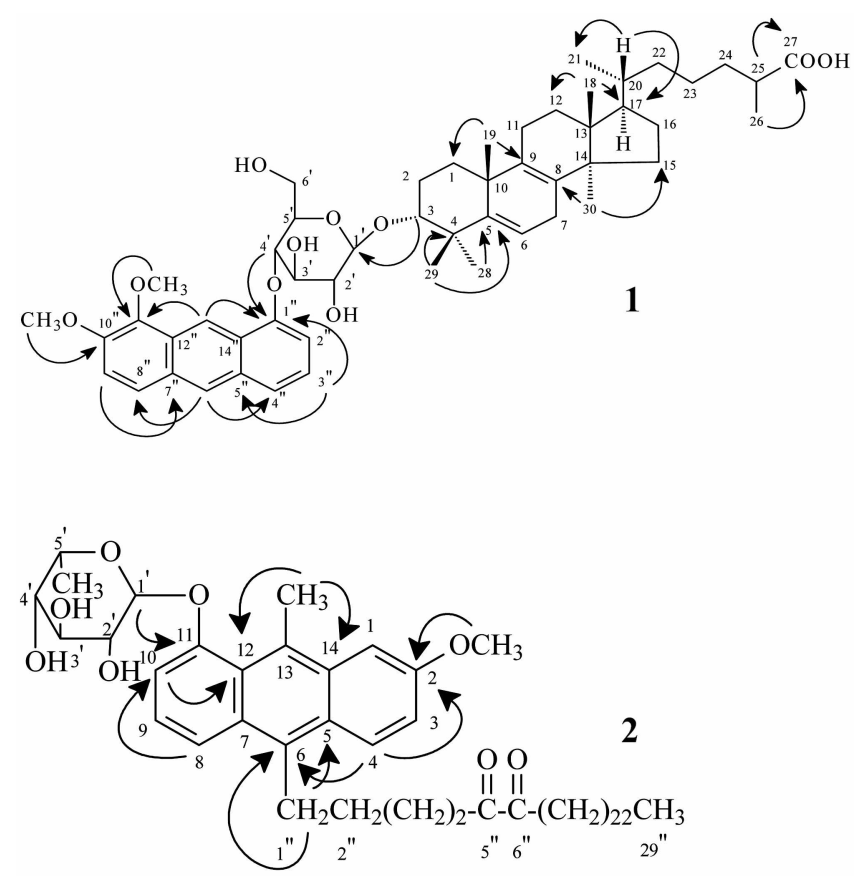

Figure 1. Key HMBC comrelations of compound 1 and 2. 

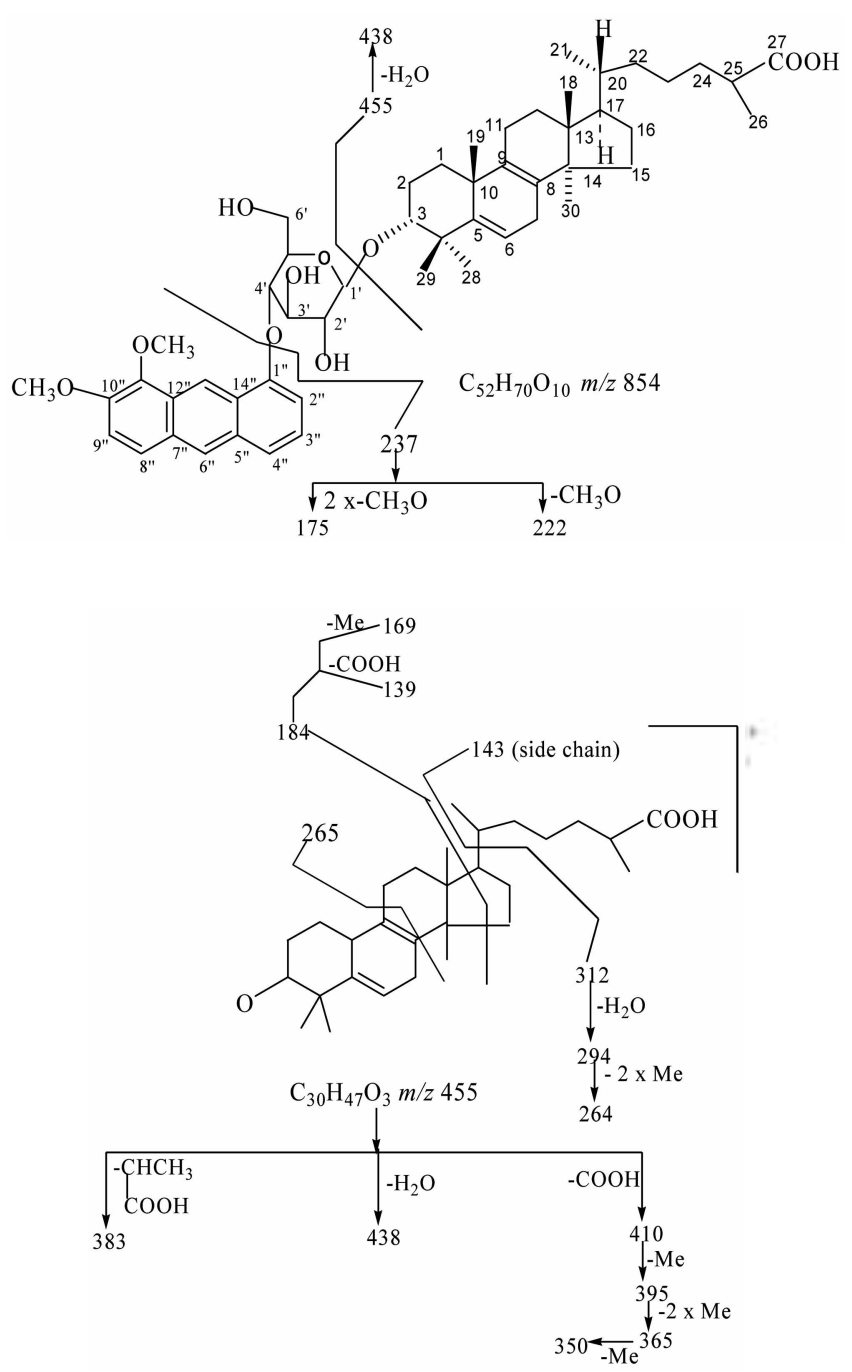

Figure 2. Fragmentation pattern of compound 1.

bands for hydroxyl groups $(3577,3415,3180 \mathrm{~cm}$ '), carboxylic group (3381, $1695 \mathrm{~cm}^{-1}$ ) and unsaturation $(1613$ $\mathrm{cm}^{-1}$ ). The positive ion FAB-MS of 1 displayed a molecular ion peak at $m / z 855$ corresponding to a tetracyclic triterpenic glycoside linked with an anthracene moiety $\mathrm{C}_{52} \mathrm{H}_{71} \mathrm{O}_{16}$. The prominent ion peaks generated at $m / z$ in the EI-MS 455 [M$\left.\mathrm{C}_{6} \mathrm{H}_{11} \mathrm{O}_{5}-\mathrm{C}_{16} \mathrm{H}_{13} \mathrm{O}_{2}\right]^{+}, 438\left[\mathrm{M}-\mathrm{C}_{6,} \mathrm{H}_{12} \mathrm{O}_{6}-\mathrm{C}_{16} \mathrm{H}_{13} \mathrm{O}_{2}\right]^{+}$, indicated that a lanostene-type triterpene carbon framework was present in the molecule. The ion fragments arose at $\mathrm{m} / \mathrm{s}$ $410[455-\mathrm{COOH}]^{+}, 395[410-\mathrm{Me}]^{-}, 365[395-2 \times \mathrm{Me}]^{+}, 383$ $\left[455-\mathrm{CH}\left(\mathrm{CH}_{3}\right) \mathrm{COOH}\right]^{+}$and $350[365-\mathrm{Me}]^{+}$suggested that the carboxylic group was present in the side chain. The ion fragments produced at $m / 2=265\left[\mathrm{C}_{8} \mathrm{H}_{14}-\mathrm{C}_{11.12} \text { fission }\right]^{-}$, $184\left[\mathrm{C}_{1+.15}-\mathrm{C}_{13.17} \text { fission }\right]^{-}, 169[184-\mathrm{Me}]^{+}, 139[184-$ $\mathrm{COOH}]^{-}, 143\left[\mathrm{C}_{8} \mathrm{H}_{14} \mathrm{O}_{2} \text { side chain }\right]^{-}, 294$ [455-side chain $\left.\mathrm{H}_{2} \mathrm{O}\right]^{-}$and 264 [294-2 $\left.\times \mathrm{Me}\right]^{-}$supported the presence of the hydroxyl group in ring $\mathrm{A}$, placed at $\mathrm{C}-3$ on the basis of biogenetic consideration, two vinylic linkages in ring $\mathrm{B}$ and saturated nature of rings $C$ and $D$. The ion peaks at $m / s 237$ was formed due to elimination of the anthracene moiety $\left[\mathrm{C}_{14} \mathrm{H}_{7}\left(\mathrm{OCH}_{3}\right)_{2}\right]^{-}$which yielded the ion peaks at $m / 222$ [237-Me $]^{-}$and $175\left[\begin{array}{lll}237-2 & \times \mathrm{OMe}\end{array}\right]^{+}$. The fragmentation pattern of compound $\mathbf{1}$ is shown in Figure 2.

The 'H NMR spectrum of 1 two one-proton ortho-, metacoupled protons at $\delta 7.12(J=7.9,3.0 \mathrm{H} 7)$ and $7.08(J=$ $7.25,3.0 \mathrm{~Hz}$ ) assigned to $\mathrm{H}-2$ " and $\mathrm{H}-4$ " respectively. "Two one-proton ortho-coupled doublets at $\delta 7.28(J=7.5 \mathrm{~Hz})$ and $7.46(J=7.5 \mathrm{~Hz})$ were attributed to $\mathrm{H}-8^{\prime \prime}$ and $\mathrm{H}-9^{\prime \prime}$ respectively. A one-proton ortho-, coupled at $\delta 7.10(J=7.9$. $7.25 \mathrm{~Hz}$ ) and two one-proton broad signals at $\delta 7.52$ and 8.14 were ascribed to $\mathrm{H}-3$ ", $\mathrm{H}-6$ " and $\mathrm{H}-13^{\prime \prime}$ respectively. A one-proton doublet at $\delta 5.32(J=2.5 \mathrm{H} 7)$ was accounted to vinylic $\mathrm{H}-6$. Three one-proton doublet at $\delta 4.42(J=7.2$ $\mathrm{Hz}), 3.12(J=10.5 \mathrm{~Hz})$ and $3.08(J=10.5 \mathrm{~Hz})$ were assigned correspondingly to anomeric $\mathrm{H}-\mathrm{l}^{1}$ and hydroxyl methylene protons $\mathrm{H}_{2}-6$. The remaining carbinol protons of the sugar moiety appeared in the range of $\delta 3.89-3.28$ as multiplets. A one-proton double doublet at $\delta 3.67$ with coupling interactions of 5.0 and $10.5 \mathrm{~Hz}$ was accounted to $\alpha$-oriented $\mathrm{H}-\hat{3}$ carbinol proton. Two three-proton doublets at $\delta 1.19(J$ $=6.65 \mathrm{~Hz}), \mathrm{I} .17(J=6.65 \mathrm{~Hz})$ were attributed to $\mathrm{C}-2 \mathrm{I}$ and C-26 secondary protons, respectively. Five three-proton broad signals at $\delta 0.88,0.93,1.11,1.25$ and 1.31 were associated with $\mathrm{C}-18, \mathrm{C}-19, \mathrm{C}-28, \mathrm{C}-29$ and $\mathrm{C}-30$ tertiary methyl protons, all attached to the saturated carbons. The remaining methylene and methine protons resonated in the range $\delta 2.98-1.31$. Two methoxy proton signals attached to $\mathrm{C}-10^{\mathrm{\prime}}$ and $\mathrm{C}-1 \mathrm{l}^{\mathrm{I}}$ showed at $\delta_{11} 3.72$ and 3.78 as broad singlets.

The ${ }^{13} \mathrm{C}$ NMR spectrum of $\mathbf{I}$ exhibited important signals for carboxylic carbon at $\delta 180.21$ (C-27), vinylic carbons at $8143,25(\mathrm{C}-5), 122.63(\mathrm{C}-6), 137.25(\mathrm{C}-8)$ and $127.96(\mathrm{C}-$ $9)$, anomeric carbon at $\delta 109.72\left(\mathrm{C}-1^{1}\right)$. sugar carbons between $\delta 60.33-69.17$ and 90.70 , carbinol carbon at $\delta$ $73.93(\mathrm{C}-3)$. methoxy carbons at $\delta 57.05$ and 53.42 and aromatic carbons between $\delta 168.73-106.88$. The multiplicity of each carbon was determined by analysis of DEPI spectrum of 1 . The ${ }^{1} \mathrm{H}-{ }^{1} \mathrm{H}$ COSY spectrum of $\mathbf{1}$ showed correlation of $\mathrm{H}-3$ with $\mathrm{H}-\mathrm{I}^{\prime}, \mathrm{H}_{2}-2, \mathrm{H}_{2}-1$ and $\mathrm{H}_{3}-28 ; \mathrm{H}-6$ with $\mathrm{H}_{2}-7, \mathrm{H}_{\mathrm{s}}-28$ and $\mathrm{H}_{3}-29 ; \mathrm{H}-2^{\prime \prime}$ with $\mathrm{H}-3^{\prime \prime}$ and $\mathrm{H}-4^{\prime \prime}$ and $\mathrm{H}-8$ " with $\mathrm{H}-9^{\prime \prime}$. The ${ }^{1} \mathrm{H}^{-1}{ }^{12} \mathrm{C}$ HËTCOR spectrum displayed interaction of $\mathrm{C}-27$ with $\mathrm{H}_{3}-26, \mathrm{C}_{-}-5$ with $\mathrm{H}_{3}-28$ and $\mathrm{H}_{3}-29$. $\mathrm{C}-4^{\prime}$ with $\mathrm{H}-5^{\prime}, \mathrm{H}_{2}-6^{\prime}, \mathrm{H}-3^{\prime}$, and $\mathrm{H}-2^{\prime \prime}$, and $\mathrm{C}-10^{\prime \prime}$ with OMe. In $\mathrm{HMBC}$ spectra. $\mathrm{H}-4$ ' showed a correlation with $\mathrm{C}$ 1 "which confirmed the connecting position of anthracene moiety to the glucose unit. Acid hydrolysis of 1 yielded Dglucose as one of the component ( [LC comparable). On the basis of spectral data analysis and chemical reactions the structure of 1 has been established as lanast-5, 8-dien- $3 \beta$-ol27-oic acid-3 $\beta$-D-glucopyranosyl (4'-1")-10". $11^{\prime \prime}$-dimethoxy anthracene. This is a new lanastenenol glycoside isolated for the first time.

Compound 2, was obtained as a dark yellow crystalline mass from $\mathrm{EtOAc:} \mathrm{MeOH}(9.5: 0.5)$ eluants. It responded positively to glycosidic tests. Its IR spectrum displayed characteristic absorption bands for hydroxyl groups ( 3423 . $\left.3380 \mathrm{~cm}^{-1}\right)$, carbonyl groups $\left(1704 \mathrm{~cm}^{-1}\right)$ and long aliphatic chain $\left(747,722 \mathrm{~cm}^{-1}\right.$ ). Its positive $\mathrm{FAB}$ MS showed a molecular ion peak at $m / z 819$ corresponding to an 


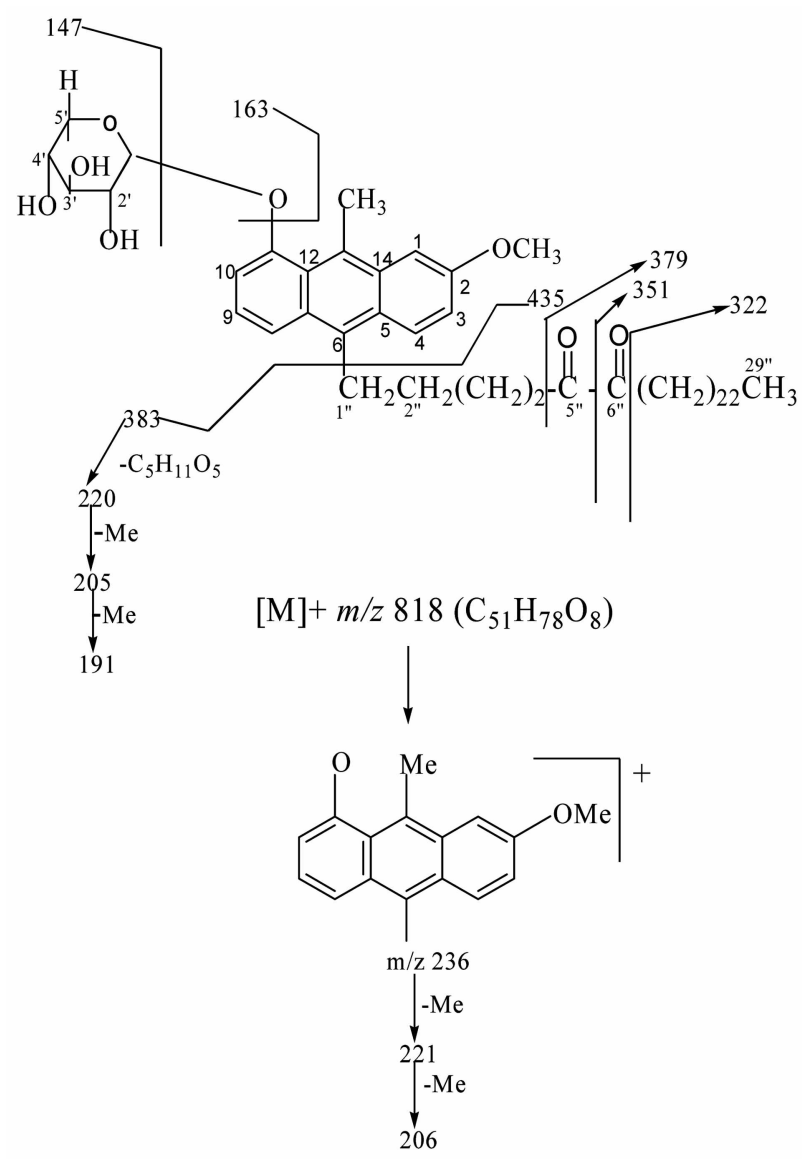

Figure 3. Fragmentation pattem of compound 2.

anthracene glycoside with $\mathrm{C}-29$ aliphatic side chain. The prominent ion peaks generated in the El MS $m / z 435$ [Manthracene glycoside], 383 [anthracene glycoside], 220 $[383 \text { - rhamnose }]^{+}, 205\left[220-\mathrm{Me}^{-}, 191[205-\mathrm{Me}]^{+}, 236\right.$ $\left[383-\mathrm{C}_{6} \mathrm{H}_{11} \mathrm{O}_{4}\right]^{+}, 221[236-\mathrm{Me}]^{-}, 206\left[221-\mathrm{Me}^{-}, 147\right.$ $\left[\mathrm{C}_{6} \mathrm{H}_{11} \mathrm{O}_{4}\right]^{+}$and $163\left[\mathrm{C}_{6} \mathrm{H}_{11} \mathrm{O}_{5}\right]^{-}$indicated that rhamnose sugar was attached to anthracene carbon framework containing a methyl, a methoxy and $\mathrm{C}_{2}$-side chain. The ion peaks arose at $m / z 379\left[\mathrm{C}_{4 "}-\mathrm{C}_{5^{\prime \prime}} \text { fission }\right]^{+}, 351\left[\mathrm{C}_{5^{\prime \prime}}-\mathrm{C}_{(1 "} \text { fission }\right]^{+}$ and $322\left[\mathrm{C}_{6,}-\mathrm{C}_{7^{\prime}} \text { fission }\right]^{+}$indicated the location of the carbonyl groups at C-5" and C-6". The fragmentation pattern of compound 2 is shown in rigure 3.

The ${ }^{\mathrm{H}} \mathrm{H}-\mathrm{NMR}$ spectrum of $\mathbf{2}$ showed a meta-coupled doublet at $\delta 7.46(J=3.0 \mathrm{~Hz})$, three meta-, ortho coupled double doublets at $\delta 7.31(J=7.5,3.0 \mathrm{~Hz}), 7.08(J=7.5,3.0$ $\mathrm{Hz})$ and $7.28(J=7.0,2.5 \mathrm{~Hz})$, one ortho-coupled doublet at $\delta 7.44(J=7.5 \mathrm{~Hz})$ and an ortho-coupled double doublet at $\delta$ $7.16(J=7.0,7.5 \mathrm{~Hz})$, assigned correspondingly to $\mathrm{H}-1, \mathrm{H}-$ $3, \mathrm{H}-8, \mathrm{H}-10, \mathrm{H}-4$ and $\mathrm{H}-9$ respectively. Two three-proton broad signals at $\delta 1.96$ and 3.74 were attributed to $\mathrm{C}-15$ methyl and $\mathrm{C}-2$ methoxy protons, respectively. $\mathrm{A}$ oneproton doublet at $\delta 4.40(J=6.0 \mathrm{~Hz})$ and a three proton doublet at $\delta 1.17(J=7.0 \mathrm{~Hz})$ were accounted to anomeric $\mathrm{H}-\mathrm{I}^{\prime}$ and secondary methyl $\mathrm{Me}-6$ ' protons. The remaining hydroxy-methine protons of the sugar moiety resonated between $\delta 3.94-3.19$. Four one-proton doublets at $\delta 2.48(\mathrm{~J}=$ $7.2 \mathrm{~Hz}), 2.43(J=7.2 \mathrm{~Hz})$ and at $\delta 2.23(J=7.1 \mathrm{~Hz})$ and $\delta$
Table 1. 'I I (500 MI Iz) and '" $\mathrm{C}$ ( I $25 \mathrm{MH} \mathrm{H} z)$ N.MR data for compound (1) in MeOD

\begin{tabular}{|c|c|c|}
\hline position & $\dot{\phi}_{\mathrm{H}}(\mathrm{ppm})$ & $\dot{\delta}_{C}(\mathrm{ppm})$ \\
\hline $1 \alpha x, 1 \beta$ & $1.98 \mathrm{~m} .2 .24 \mathrm{~mm}$ & 33.061 \\
\hline $2 \alpha \cdot 2 \beta$ & $2.41 \mathrm{~m} .1 .31 \mathrm{~m}$ & $27.42 \mathrm{l}$ \\
\hline 3 & $3.67 \mathrm{dd}(5.0 .10 .5)$ & $73.93 \mathrm{~d}$ \\
\hline 4 & - & $45.01 \mathrm{~s}$ \\
\hline 5 & - & $143.25 \mathrm{~s}$ \\
\hline 6 & $5.32 \mathrm{~d}(2.5)$ & $122.63 \mathrm{~d}$ \\
\hline $7 e x, 7 \beta$ & $2.98 \mathrm{~d}(2.5) .2 .96 \mathrm{~d}(2.5)$ & 50.861 \\
\hline 8 & - & $137.25 \mathrm{~s}$ \\
\hline 9 & - & $127.96 \mathrm{~s}$ \\
\hline 10 & - & $39.38 \mathrm{~s}$ \\
\hline $1|\alpha| 1 \beta$ & $2.75 \mathrm{dd}(4.5 .9 .1) .2 .68 \mathrm{dd}(4.5 .5 .0)$ & 50.191 \\
\hline $12 \alpha .12 \beta$ & $2.04 \mathrm{dd}(4.5 .9 .1) \cdot 1.72 \mathrm{dd}(4.5 .5 .0)$ & $29.90 \mathrm{t}$ \\
\hline 13 & - & $45.49 \mathrm{~s}$ \\
\hline 14 & - & $51.42 s$ \\
\hline $15 \alpha .15 \beta$ & $1.36 \mathrm{~m} .1 .34 \mathrm{~m}$ & $30.85 \mathrm{t}$ \\
\hline $16 \% .16 \beta$ & $1.94 \mathrm{~m} .2 .22 \mathrm{~m}$ & $29.52 \mathrm{t}$ \\
\hline 17 & $2.22 \mathrm{~m}$ & $51.26 \mathrm{~d}$ \\
\hline 18 & 0.88 brs & $13.89 \mathrm{q}$ \\
\hline 19 & $1.11 \mathrm{bes}$ & $1907 \mathrm{q}$ \\
\hline 20 & $2.70 \mathrm{~m}$ & $41.14 \mathrm{~d}$ \\
\hline 21 & $1.19 \mathrm{~d}(6.6)$ & $21.97 \mathrm{q}$ \\
\hline $22 \alpha .22 \beta$ & $2.41 \mathrm{m.} 201 \mathrm{~m}$ & $29.44 \mathrm{t}$ \\
\hline $23 \alpha .23 \beta$ & $1.36 \mathrm{~m} .1 .64 \mathrm{~m}$ & 29,321 \\
\hline $24 \alpha .24 \beta$ & $1.42 \mathrm{~m} .2 .01 \mathrm{~m}$ & $23.68 \mathrm{t}$ \\
\hline 25 & $2.70 \mathrm{~m}$ & $23.68 \mathrm{~d}$ \\
\hline 26 & $1.17 \mathrm{~d}(6.6)$ & $30.85 q$ \\
\hline 27 & - & $180.21 \mathrm{~s}$ \\
\hline 28 & $0.93 \mathrm{hrs}$ & $14.31 \mathrm{q}$ \\
\hline 29 & $1.25 \mathrm{brs}$ & $15.16 \mathrm{q}$ \\
\hline 30 & $1.31 \mathrm{brs}$ & $32.13 \mathrm{q}$ \\
\hline $\mathrm{l}^{\mathrm{r}}$ & $4.42 \mathrm{~d}(7.2)$ & $109.72 \mathrm{~d}$ \\
\hline $2^{\prime}$ & $3.75 \mathrm{~m}$ & $69.17 \mathrm{~d}$ \\
\hline $3^{r}$ & $3.38 \mathrm{~m}$ & $64.57 \mathrm{~d}$ \\
\hline $4^{\prime}$ & $3.28 \mathrm{~m}$ & $6.3 .88 \mathrm{~d}$ \\
\hline $5^{\prime}$ & $3.89 \mathrm{~m}$ & $90.70 \mathrm{~d}$ \\
\hline $6^{\prime} \alpha .6^{\prime} \beta$ & $3.12 \mathrm{~d}(10.5) .3 .08 \mathrm{~d}(10.5)$ & $60.33 \mathrm{t}$ \\
\hline$l^{1+}$ & - & $167.68 \mathrm{~s}$ \\
\hline $2^{\prime \prime}$ & $7.12 \mathrm{dd}(7.9 .3 .0)$ & $154.90 \mathrm{~d}$ \\
\hline $3^{\prime \prime}$ & $7.10 \mathrm{dd}(7.9 .7 .2)$ & $111.07 \mathrm{~d}$ \\
\hline $4^{\prime \prime}$ & $7.08 \mathrm{dd}(7.2 .3 .0)$ & $118.24 \mathrm{~d}$ \\
\hline $5^{\prime \prime}$ & - & $127.47 \mathrm{~s}$ \\
\hline $6^{\prime \prime}$ & $7.52 \mathrm{~s}$ & $121.08 \mathrm{~d}$ \\
\hline $7^{\prime \prime}$ & - & $106.88 \mathrm{~s}$ \\
\hline $8^{\prime \prime}$ & $7.28 \mathrm{~d}(7.5)$ & $127.96 \mathrm{~d}$ \\
\hline $9^{\prime \prime}$ & $7.46 \mathrm{~d}(7.5)$ & $121.04 \mathrm{~d}$ \\
\hline $10^{\prime \prime}$ & - & $168.60 \mathrm{~s}$ \\
\hline $1{ }^{\prime \prime}$ & - & $168.73 \mathrm{~s}$ \\
\hline $12^{\prime \prime}$ & - & $108.05 \mathrm{~s}$ \\
\hline $13^{\prime \prime}$ & $8.14 s$ & $121.58 \mathrm{~d}$ \\
\hline $14^{\prime \prime}$ & - & $136.22 s$ \\
\hline $\mathrm{OMc}$ & $\begin{array}{l}3.72 \text { brs } \\
3.78 \text { brs }\end{array}$ & $\begin{array}{l}57.05 q \\
53.42 q\end{array}$ \\
\hline
\end{tabular}

$J$ values (it) $\mathrm{H}$ 7) are in parenthesis.

$2.21(J=7.1 \mathrm{~Hz})$ were attributed to methylene $\mathrm{H}_{2}-4^{\prime \prime}$ and $\mathrm{H}_{2}-7^{\prime \prime}$ protons adjacent to the carbonyl groups. A threeproton triplet at $\delta 0.86(J=7.0 \mathrm{~Hz})$ was due to $\mathrm{C}-29^{\prime \prime}$ 
primary metlyl protons. The remaining methylene protons of the aliphatic side chain resonated between $\delta 2.07-1.25$.

The ${ }^{13} \mathrm{C}-\mathrm{NMR}$ spectrum of 2 showed aromatic carbon signals between $\delta$ 167.48-106.39, anomeric carbon at $\delta$ $111.62\left(\mathrm{C}-\mathrm{l}^{\prime}\right)$. hydroxy-methine carbons of the sugar moiety between $876.98-65.64$, carbonyl carbons at $8207.13(\mathrm{C}-5 ")$ and $195.69\left(\mathrm{C}-6^{\prime \prime}\right)$, methoxy carbon at $\delta 51.41$. methyl carbons at $\delta 15.32(\mathrm{Me}-15) .26 .34(\mathrm{Me}-6)$ and $14.33(\mathrm{Me}-$ 29 ") and the remaining methylene carbons between $\delta 35.22$ 18.61 (Table 2). The multiplicity of each carbon was determined by analysis of the DEPT spectrun of 2. In $^{1} \mathrm{H}-{ }^{1} \mathrm{H}$ COSY spectrum of 2 correlations of $\mathrm{Me}-15$ were observed with $\mathrm{H}-1$ : Me-6' with $\mathrm{H}-4$ '. $\mathrm{H}-3$ ' and $\mathrm{H}-2$ '; $\mathrm{H}-3$ with $\mathrm{H}-1$ and $\mathrm{H}-4 ; \mathrm{H}_{2}-\mathrm{I}^{\prime \prime}$ with $\mathrm{H}-4$ and $\mathrm{H}-8$ and $\mathrm{H}_{3}-29^{\prime \prime}$ with the adjacent methylene protons. In HMBC spectrum of $2, \mathrm{C}-11$ showed a correlation with $\mathrm{H}-\mathrm{l}$ ' which indicates the $\mathrm{D}$ rhammose is connected at $\mathrm{C}-\mathrm{Il}$ of the athracene moiety. The connecting position of the aliphatic group in $\mathbf{2}$ was decided from the $\mathrm{HMBC}$ correlation between $\mathrm{H}-1$ " and $\mathrm{C}-5 / \mathrm{C} \cdot 6 / \mathrm{C}-7$ as well as $\mathrm{H}-2$ " and $\mathrm{C}-6$.

Acid hydrolysis of 2 yielded a D-rhamnose as a glycone moiety (TLC conparable). On the basis of the foregoing account the structure of $\mathbf{2}$ has been established as 2-methoxy6-(n-nonacontanl-5".6"-dionyl)-11-hydroxy-13-methyl-11 $\beta$-Drhanmopyranoside antluracene. This is new anthracene derivative isolated for the first time.

\section{Experimental Section}

Chemicals. All chemicals were of an analytical grade: hexane. ethyl acetate, methanol. ethanol, sulphuric acid and vanillin were purchased from Daejung Chemicals and Metals (Seoul. South Korea). Pre-coated TLC plates (layer thickness $0.5 \mathrm{~mm}$ ), silica gel for column chromatography (70-230 mesh ASTM) and LiChroprep RP-18 (40-63 $\mu \mathrm{m})$ were from Merck (Darmstadt, Gennany). Authentic standards of $\beta$-sitosterol. oleic acid, and D-glucose were purchased from Sigma-Aldrich (St. Louis. MO, USA).

Instrumentation. Melting points were determined using Electrochemical Engineering (Electrothermal. Seoul. South Korea) model IA9100 melting point apparatus. Specific rotation was measured with an instruments Ltd (Seoul. South Korea) model AA-10 polarimeter. ${ }^{1} \mathrm{H}$ - and ${ }^{13} \mathrm{C}-\mathrm{NMR}$ spectra were obtained at 500 and $125 \mathrm{MHz}$, respectively. using a Bruker Avance model DRX-500 spectrometer at the Seoul National University (SNU). Seoul. South Korea. NMR spectra were obtained in deuterated chloroform and methanol using tetramethylsilane (TMS) as an internal standard. EI/MS and FAB/MS were recorded on JEOL JMSSX 102A and JEOL JMS-AX 505WA spectrophotometers. respectively. at the Seoul National University. IR spectra were recorded on a Thermo Mattson Infinity Gold FT-IR model 60-AR spectrophotometer at the Korea Institute of Science and Technology (KIST) Seoul. South Korea.

Culture conditions. The hairy root line used in this study was previously generated by infection of $C$. rosetis seedling with Agrobacterium rhizogenes $15834^{1+}$ The culture media
Table 2. ${ }^{1} \mathrm{H}(500 \mathrm{MHz})$ and ${ }^{13} \mathrm{C}(125 \mathrm{MHz}) \mathrm{NMR}$ data for compound (2) in $\mathrm{MeOD}$

\begin{tabular}{|c|c|c|}
\hline position & $\delta_{\mathrm{H}}(\mathrm{ppm})$ & $\delta_{c}(\mathrm{ppm})$ \\
\hline l & $7.46 \mathrm{~d}(3.0)$ & $155.44 \mathrm{~d}$ \\
\hline 2 & - & $167.48 \mathrm{~s}$ \\
\hline 3 & $7.31 \mathrm{dd}(7.5,3.0)$ & $122.56 \mathrm{~d}$ \\
\hline 4 & $7.44 \mathrm{~d}(7.5)$ & $118.67 \mathrm{~d}$ \\
\hline 5 & - & $105.33 \mathrm{~s}$ \\
\hline 6 & - & $150.16 \mathrm{~s}$ \\
\hline 7 & - & $106.39 \mathrm{~s}$ \\
\hline 8 & $7.08 \mathrm{dd}(7.5,3.0)$ & $118.67 \mathrm{~d}$ \\
\hline 9 & $7.16 \mathrm{dd}(7.0,7.5)$ & $124.39 \mathrm{~d}$ \\
\hline 10 & $7.28 \mathrm{dd}(7.0,2.5)$ & $120.26 \mathrm{~d}$ \\
\hline 11 & - & $167.48 \mathrm{~s}$ \\
\hline 12 & - & $126.71 \mathrm{~s}$ \\
\hline 13 & - & $136.49 \mathrm{~s}$ \\
\hline 14 & - & $122.56 \mathrm{~s}$ \\
\hline 15 & $1.96 \mathrm{brs}$ & $15.32 \mathrm{q}$ \\
\hline $\mathrm{OMe}$ & $3.74 \mathrm{brs}$ & $51.41 \mathrm{q}$ \\
\hline$l^{\prime}$ & $4.44 \mathrm{~d}(6.0)$ & $111.62 d$ \\
\hline $2^{\prime}$ & $3.94 \mathrm{~m}$ & $76.98 \mathrm{~d}$ \\
\hline 3 & $3.24 \mathrm{~m}$ & $65.64 d$ \\
\hline 4 & $3.19 \mathrm{~m}$ & $71.03 \mathrm{~d}$ \\
\hline 5 & $3.51 \mathrm{~m}$ & $72.51 \mathrm{~d}$ \\
\hline $6^{\prime}$ & $1.17 \mathrm{~d}(7.0)$ & $26.34 \mathrm{q}$ \\
\hline$l^{\prime \prime} \alpha, 1^{\prime \prime} \beta$ & $2.87 \mathrm{brs}, 2.85 \mathrm{brs}$ & $35.22 \mathrm{t}$ \\
\hline $2^{\prime \prime} \alpha, 2^{\prime \prime} \beta$ & $2.04 \mathrm{~m}, 2.07 \mathrm{~m}$ & $33.41 \mathrm{t}$ \\
\hline $3^{\prime \prime} \alpha, 3^{\prime \prime} \beta$ & $1.96 \mathrm{~m}, 1.94 \mathrm{~m}$ & $30.14 \mathrm{t}$ \\
\hline $4^{\prime \prime} \alpha, 4^{\prime \prime} \beta$ & $2.48 \mathrm{~d}(7.2), 2.43 \mathrm{~d}(7.2)$ & $32.15 \mathrm{t}$ \\
\hline $5^{\prime \prime}$ & 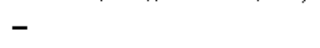 & $207.13 \mathrm{~s}$ \\
\hline $6^{1}$ & - & $195.69 \mathrm{~s}$ \\
\hline $7^{\prime} \alpha, 7^{\prime \prime} \beta$ & $2.23 \mathrm{~d}(7.1), 2.21(7.1)$ & $30.38 \mathrm{t}$ \\
\hline $8^{\prime \prime} \alpha, 8^{\prime \prime} \beta$ & $1.62 \mathrm{~m}, 1.60 \mathrm{~m}$ & $30.14 \mathrm{t}$ \\
\hline $9^{\prime \prime} \alpha, 9^{\prime \prime} \beta$ & $1.35 \mathrm{~m}, 1.33 \mathrm{~m}$ & $30.38 \mathrm{t}$ \\
\hline $10^{\prime \prime} \alpha, 10^{\prime \prime} \beta$ & 1.28 br s, 1.28 br s & $30.14 t$ \\
\hline $11^{\prime \prime} \alpha, 11^{\prime \prime} \beta$ & $1.28 \mathrm{brs}, 1.28$ br s & $29.92 \mathrm{t}$ \\
\hline $12^{\prime \prime} \alpha, 12^{\prime \prime} \beta$ & $1.28 \mathrm{brs}, 1.28 \mathrm{brs}$ & $29.92 \mathrm{t}$ \\
\hline $13^{\prime \prime} \alpha, 13^{11} \beta$ & 1.28 br $s, 1.28$ br s & $29.92 \mathrm{t}$ \\
\hline $14^{\prime \prime} \alpha, 14^{1} \beta$ & $1.28 \mathrm{brs}, 1.28 \mathrm{brs}$ & $29.92 \mathrm{t}$ \\
\hline $15^{\prime \prime} \alpha, 15^{\prime \prime} \beta$ & $1.28 \mathrm{br} \mathrm{s}, 1.28 \mathrm{brs}$ & $29.92 \mathrm{t}$ \\
\hline $16^{\prime \prime} \alpha, 16^{\prime \prime} \beta$ & $1.28 \mathrm{brs}, 1.28$ br s & $29.92 \mathrm{t}$ \\
\hline $1^{\prime \prime} \alpha, 17^{\circ} \beta$ & 1.28 br $\mathrm{s}, 1.28 \mathrm{brs}$ & $29.92 \mathrm{t}$ \\
\hline $18^{\prime \prime} \alpha, 18^{\prime \prime} \beta$ & $1.28 \mathrm{brs}, 1.28 \mathrm{brs}$ & $29.92 \mathrm{t}$ \\
\hline $19^{\prime \prime} \alpha, 19^{\prime \prime} \beta$ & $1.28 \mathrm{br} \mathrm{s}, 1.28$ br s & $29.92 t$ \\
\hline $20^{\prime \prime} \alpha, 20^{\prime \prime} \beta$ & $1.28 \mathrm{brs}, 1.28$ br s & $29.92 \mathrm{t}$ \\
\hline $21^{11} \alpha, 21^{1 \circ} \beta$ & $1.28 \mathrm{br} s, 1.28 \mathrm{brs}$ & $29.92 \mathrm{t}$ \\
\hline $22^{\prime \prime} \alpha, 22^{\prime} \beta$ & $1.28 \mathrm{brs}, 1.28 \mathrm{brs}$ & $29.92 \mathrm{t}$ \\
\hline $23^{\prime \prime} \alpha, 23^{\prime \prime} \beta$ & $1.25 \mathrm{brs}, 1.28 \mathrm{brs}$ & $29.58 \mathrm{t}$ \\
\hline $24^{\prime \prime} \alpha, 24^{\prime \prime} \beta$ & $1.25 \mathrm{brs}, 1.25 \mathrm{br} \mathrm{s}$ & $29.58 \mathrm{t}$ \\
\hline $25^{\prime \prime} \alpha, 25^{\prime \prime} \beta$ & 1.25 br s, $1.25 \mathrm{brs}$ & $29.58 \mathrm{t}$ \\
\hline $26^{\prime \prime} \alpha, 26^{\prime \prime} \beta$ & $1.12 \mathrm{~m}, 1.11 \mathrm{~m}$ & $22.91 \mathrm{t}$ \\
\hline $27^{\prime \prime} \alpha, 27^{\prime} \beta$ & $1.25 \mathrm{brs}, 1.25 \mathrm{br} \mathrm{s}$ & $18.61 \mathrm{t}$ \\
\hline $28^{\prime \prime} \alpha, 28^{\prime \prime} \beta$ & $1.25 \mathrm{brs}, 1.25$ br s & $18.61 \mathrm{t}$ \\
\hline $29^{\prime \prime}$ & $0.86 t(7.0)$ & $14.33 \mathrm{q}$ \\
\hline
\end{tabular}

$J$ ralues (in $\mathrm{Hz}$ ) are in parenthesis.

consisted of a filter-sterilized solution of $3 \%$ sucrose. halfstrength Gauborg's B5 salts and full-strength Gamborg's vitamins with the $\mathrm{pH}$ adjusted to 5.7 . The $50-\mathrm{mL}$ cultures 
were grown in 250-mL Erlenmeyer flasks to late exponential phase in the dark at $26^{\circ} \mathrm{C}$ at 100 rpm.

Extraction of hairy roots. The powdered hairy roots of C. rosets ( $200 \mathrm{~g}$ ) were immersed in methanol ( 1.5 litre) for three days at room temperature and then the supernatant was concentrated under vacuum to yield $22.5 \mathrm{~g}$ of the extract. This material was suspended in water and extracted with ethyl acetate and $n$-butanol successively to produce $11.2 \mathrm{~g}$ of ethyl acetate and $7.4 \mathrm{~g}$ of $n$-butanol extract.

Isolation of the compounds from ethyl acetate extract. The entire etlyl acetate extract was subjected to normal phase CC over silica gel $(400 \mathrm{~g})$ to yield each of $500 \mathrm{~mL}$ fractions using the eluent of $n$-hexane (fraction 1 ), the mixtures of $n$-hexane:ethyl acetate at $9: 1$ (fraction 2), 8:2 (fraction 3), 7:3 (fraction 4). 1:1 (fraction 5). and 3:7 (fraction 6) ratio $(\mathrm{v} / \mathrm{v})$, ethyl acetate (fraction 7 ). the mixtures of ethyl acetate:methanol at 9.5:0.5 (fraction 8). 9:1 (fraction 9), 7:3 (fraction 10). 1:1 (fraction 11). and 3:7 (fraction 12) ratio $(v / v)$. and methanol (fraction 13 ). respectively. All fractions were exanined by TLC. Fractions 1 and 2 was not further separated due to the low amount of substance. Fractions $3(0.8 \mathrm{~g})$ was crystallized after the purification by $\mathrm{CC}$. and then yielded $\beta$-sitosterol $(20 \mathrm{mg}$ ) whose identity was confirmed through the comparison of TLC with an authentic sample from Signa and spectroscopic data $\left({ }^{1} \mathrm{H}\right.$ NMR and ${ }^{13} \mathrm{C}$ NMR. EI MS). Fractions $4(0.6 \mathrm{~g})$ was further purified by $\mathrm{CC}$ over silica gel ( $100 \mathrm{~g}$ : each fraction of 100 $\mathrm{mL}$ ) eluting with dichloromethane and chloroform:methanol mixtures (99:1. 98.5:1.5 [fraction ii], 98.2:1.8 [fraction iii]. $97.5: 2.5$ [fraction iv]. and $97: 3$ [fraction $v$ ]. $v / v$ ) to afford 3 epibetulinic acid (120 mig). Fraction 6 with hexane:ethyl acetate $(3: 7, v / v)$, after re-separation by $\mathrm{CC}$ over silica gel with chloroform:methanol (99:1 [fraction i], 98:2 [fraction ii], $97: 3$ [fraction iii]. 96:4 [fraction iv], and 95:5 [fraction $v$ ]. $v / v$ ). afforded five fractions. Fraction iv (from the eluent of $\left.\mathrm{CHCl}_{3} \mathrm{MeOH}(96: 4, \mathrm{v} / \mathrm{v})\right)$ was re-chromatographed over Lichroprep RPI8 ODS (50 g: each fraction of $50 \mathrm{~mL}$ ). The elution was sequentially performed with methanol containing $80.60,4020,10$. and $0 \%$ of water to yield $n$-pentadecanyl octa-dec-19-en-oate (23 mg). Fraction 9 with EtOAc$\mathrm{MeOH}(9: 1)$ after rechromatography over Lichroprep RP18 ODS (50 g: each fraction of $50 \mathrm{~mL}$ ). The elution was sequentially performed with methanol containing $80,60,40$ 20. 10 . and $0 \%$ of water to yield two new compounds. (1) (17 mg) and (2) (27 mg), in the methanol fraction containing $60 \%$ of water.

Lanast-5,8-dien-3 $\beta$-0l-27-oic acid-3 $\beta$-D-glucopyranosyl(4'-1")-10",11"-dimethoxy anthracene (1). Dark yellow solid: $m p$ 223-225 ${ }^{\circ} \mathrm{C}:[\alpha]_{\mathrm{D}}^{22}+38.1^{\circ}$ (c 0.21 . MeOH); IR (KBr) $v_{\text {max }} \mathrm{cm}^{-1}: 3577.3415 .3381 .3180,2920,2855.1695$. 1613. 1441. 1350. 1298, 1191. 1107, $744 \mathrm{~cm}^{-1}$. EIMS $m: z$ $455\left[\mathrm{M}-\mathrm{C}_{23} \mathrm{H}_{23} \mathrm{O}_{7}\right]^{-}$(1.8). $438(1.1), 410(1.0), 395$ (2.8). 383 (1.4), $380(2.2) .365(3.5), 355(5.5) .351(100), 265(7.1)$. $237(8.0), 222(7.4) .184(28.0) .175(5.0), 143(7.1), 139$ (5.3): positive ion FABMS $m z 855[\mathrm{M}+\mathrm{H}]^{+} \mathrm{C}_{30} \mathrm{H}_{71} \mathrm{O}_{10}$ (l.6). Negative ion FABMS $m z+55\left[\mathrm{M}-\mathrm{C}_{2 \geq} \mathrm{H}_{23} \mathrm{O}_{7}\right]^{-}:$HRFABMS $m z 855.5042[\mathrm{M}+\mathrm{H}]^{+}\left(\mathrm{C}_{52} \mathrm{H}_{71} \mathrm{H}_{1}\right.$ l. calculated for 855.5047$)$ : ${ }^{1} \mathrm{H}$ NMR (MeOD, $500 \mathrm{MHz}$ ) and ${ }^{13} \mathrm{C}$ NMR (MeOD. 125 $\mathrm{MHz}$ ) (Table 1).

Acid hydrolysis: Compound 1 (5 $\mathrm{mg}$ ) was refluxed with 2 $\mathrm{mL}$ of $1 \mathrm{M}$ hydrochloric acid:dioxane $(1: 1, v / v)$ in a water bath for $4 \mathrm{~h}$. The reaction mixture was evaporated to dryness and partitioned with chloroform and water four times. and each extract was concentrated. The chloroform extract contained the aglycone portion, while the water extract contained D-glucose (co-cluromatographed on TLC with authentic sample).

2-Methoxy-6-(n-nonacontan-5",6"'-dionyl)-11-hydroxy13-methyl-11 $\beta$-D-rhamnopyranoside anthracene (2). Dark yellow solid: $\operatorname{mp} 228-229^{\circ} \mathrm{C}:[\alpha]_{\mathrm{D}}^{2-}+27.1^{\circ}(c 0.12 . \mathrm{MeOH})$; IR (KBr) $v_{\text {nax }} \mathrm{cm}^{-1}: 3423.3380,2924,2853.1704,1617$, 1459. 1301, 1290, 1192, 1096. 747, 722; FABMS $m z 819$ $[\mathrm{M}+\mathrm{H}]^{+}\left(\mathrm{C}_{51} \mathrm{H}_{79} \mathrm{O}_{8}\right)$; EIMS $m z$ (rel.int $) 435\left[\mathrm{M}-\mathrm{C}_{22} \mathrm{H}_{23} \mathrm{O}_{6}\right.$. $\left.\mathrm{C}_{20} \mathrm{H}_{55} \mathrm{O}_{2}\right]^{+}$(5.4). 379 (5.5). 351 (4.6). 322 (5.0). $236(5.3)$. 221 (14.9). $220(4.8), 205(6.2), 206(7.6) .195$ (10.1). 191 (7.8). $183(31.5) .155(39.3), 139(3.6), 125(5.6), 111(7.5), 97$ (10.1), $85(10.0) .83(9.7) .71(12.6), 57(100)$ : ${ }^{1} \mathrm{H}$ NMR (MeOD. $500 \mathrm{MHz}$ ) and ${ }^{13} \mathrm{C}$ NMR (MeOD. $125 \mathrm{MHz}$ ) (Table 2).

Acid hydrolysis: Compound 2 (5 $\mathrm{mg}$ ) was refluxed with 2 $\mathrm{mL}$ of $1 \mathrm{M}$ hydrochloric acid:dioxane $(1: 1, v / v)$ in a water bath for $4 \mathrm{~h}$. The reaction mixture was evaporated to dryness and partitioned with chlorofonm and water four times. and each extract was concentrated. The chloroform extract contained the aglycone portion, while the water extract contained D-rhamnose (co-chromatographed on TLC with authentic sample).

Acknowledgments. This work was supported by Institute of Biomedical Science and Technology (IBST-2004-1) of Konkuk University

\section{References}

1. Taylor. W. I.: Farnsworth. N. R. The Cathoranthis Alkaloids: Marcel Dekker: New York. 1975.

2. Chockalingam, S.: Nalina Sundari. M. S.: Thenmozhi, S. $J$. Environ. Biol. 1989, 10.303.

3. Luijendijk, T. J. C.; Van der, M. E; Verpoorte, R. J. Chemical Ecolog1 1996. 22. 1355.

4. Leveque. D: Wihlm1. J.: Tehl. F. Bull. Cancer 1996. 83.176.

5. Farnsworth. N. R. Joumal of Natural Products 1961. 24. 105.

6. Daniel, M.: Sabnis. S. D. Indian J. Exp. Biologv 1978. 16. 512.

7. Nishibe, S: Takenaka. T.: Fujikawa, T: Yasukawa, K: Takido. M: Moritsu, Y:; Hirota, A.: Kawamura, K.: Noro. Y. Natual Medicine (Tokyo) 1996.50.378.

8. Van der. H. R.: Verpoorte. R.: Ten Hoopen. H. I. G. Plam Cell Tiss. Org Cult 1989.18.231.

9. Moreno. P. R. H.: Van der, H. R:; Verpoorte. R. Plant Cell Tiss Org. Cult $1995,+2,1$.

10. Moreno, P. R. H.: Poulsen, C.: Heijden, R. V; Verpoorte, R Enzinte and Hicrobial Technologv 1996. 18.99.

11. Knobloch. K. H.: Bast. G.: Berlin. T. Phytochentistry 1982. 21.591.

12. Seitz. H. U.: Eilert. U.: De Luca. V: Kurz. W. G. W. Plam Cell Tiss. Org. Cult. 1989. 18.71.

13. Chung. I. M.; Park. H. Y; Ali. M.; San, K. Y: Peebles, C. A. M. Hong. S. B.: Ahmad A. Bull Korean Chem. Soc. 2007. 28, 229.

14. Bhadra. R.: Vani. S.: Shanks. T. Biotechnol Bioeng. 1993. +1.581. 